\begin{abstract}
Iranica
Abstracta Iranica Revue bibliographique pour le domaine irano-aryen

Volume 34-35-36 | 2017

Comptes rendus des publications de 2011-2013
\end{abstract}

\title{
D. Klotz. Administration of the Desert and Oases: First Millennium B.C.E.
}

\section{Sépideh Qaheri-Paquette}

\section{(2) OpenEdition}

Édition électronique

URL : http://journals.openedition.org/abstractairanica/41733

DOI : 10.4000/abstractairanica.41733

ISSN : 1961-960X

Éditeur :

CNRS (UMR 7528 Mondes iraniens et indiens), Éditions de l'IFRI

Référence électronique

Sépideh Qaheri-Paquette, « D. Klotz. Administration of the Desert and Oases: First Millennium B.C.E. », Abstracta Iranica [En ligne], Volume 34-35-36 | 2017, document 102, mis en ligne le 30 décembre 2016, consulté le 26 septembre 2020. URL : http://journals.openedition.org/abstractairanica/41733 ; DOI : https://doi.org/10.4000/abstractairanica.41733

Ce document a été généré automatiquement le 26 septembre 2020.

Tous droits réservés 


\title{
D. Klotz. Administration of the Desert and Oases: First Millennium B.C.E.
}

\author{
Sépideh Qaheri-Paquette
}

\section{RÉFÉRENCE}

D. Klotz. « Administration of the Desert and Oases: First Millennium B.C.E. », in : J.-C. Moreno-Garcia, éd., Ancient Egyptian Administration. Leyde-Boston, Brill, 2013, p. 901-909. (HdO I.104)

1 Parue dans un très utile volume consacré à l'administration de l'Égypte pharaonique, cette contribution décrit brièvement l'organisation économique et administrative des oasis égyptiennes au cours du premier millénaire av. J.-C. L'analyse se base sur les sources textuelles et archéologiques datant de la Troisième Période Intermédiaire jusqu'à l'époque ptolémaïque (1069- 30 av. n.è.). La période « saïto-perse » (664-404) est ici présentée comme une phase clé pendant laquelle les activités dans les déserts s'accroissent considérablement. Tout en rappelant l'importance du contrôle des zones frontalières de l'Égypte pour l'Empire achéménide, l'A. évoque trois régions d'intervention aux marges de la vallée du Nil à l'époque perse : le Sinaï et les deux déserts oriental et occidental. L'intérêt géographique, stratégique et économique de chacune de ces régions ainsi que les sites et données majeurs sont indiqués avec plus au moins de détails. Un paragraphe conclusif de cette partie met en avant l'extension sous les Achéménides du réseau des routes dans le désert occidental. 


\section{AUTEURS}

\section{SÉPIDEH QAHERI-PAQUETTE}

Université Lyon 2 